\title{
Confirmatory Factor Analysis and Norming of the High School Student's Entrepreneurial Orientation Scale
}

\author{
Jimmy Ellya Kurniawan ${ }^{1 *}$, Ersa Lanang Sanjaya1, Stefani Virlia ${ }^{1}$ \\ ${ }^{1}$ School of Psychology, Universitas Ciputra, Indonesia \\ *Correspondence: jimmy.ellya @ ciputra.ac.id
}

\begin{abstract}
Several studies have shown that entrepreneurial orientation in high school students can predict career choices as businessmen in the future. However, not many studies have developed a measurement instrument for entrepreneurial orientation in high school students in one solid variable construct. This study aims to conduct confirmatory factor analysis and norming on a scale that was previously explored. A survey of 646 high school students was conducted in six large cities throughout the provinces on Java Island, Indonesia. The results of this research confirmed that the construct of entrepreneurial orientation in high school students has three dimensions: innovativeness, risky proactiveness and competitiveness. The study also produced a norm index for junior and senior high school students. This scale will be useful in mapping the level of student's entrepreneurial orientation and assist high school management bodies to prepare programs that are more suitable to developing entrepreneurial behavior in students.
\end{abstract}

Keywords

Entrepreneurial; High school; Student; Scale; Adolescence

Article Received: 16 ${ }^{\text {th }}$ October, 2020; Article Revised: $30^{\text {th }}$ December, 2020; Article Accepted: 08 ${ }^{\text {th }}$ January, 2021

\section{Introduction}

A person's career choice to be self-employed or a business owner can be predicted through their entrepreneurial orientation since adolescence or while they are in high school. Schmitt-Rodermund \& Vondracek (2002) proved that entrepreneurial orientation is an important predictor of the entrepreneurial prospects of $10^{\text {th }}$ grade students (aged 14-17 years old), i.e. the desire to be self-employed when they are 40 years old. A longitudinal study of thousands of high school students in the US showed that a student's entrepreneurial orientation influences their future career prospects of establishing a business in ten years' time (Saw \& Schneider, 2012).

Unfortunately, not many studies have developed measurement instruments for entrepreneurial orientation in high school students. Schmitt-Rodermund \& Vondracek (2002) measured entrepreneurial orientation based on three variables: entrepreneurial interest, entrepreneurial skills and entrepreneurial behavioral traits. Meanwhile, Saw \& Schneider (2012) measured entrepreneurial orientation without using a scale, but based on a single question about occupational aspirations to be a business owner, which were seen as an indication of entrepreneurial orientation in adolescence. Although these two studies prove the strong role of entrepreneurial orientation as a predictor of one's future career, not many studies have developed a high school entrepreneurial orientation scale specifically developed based on one solid construct variable.

This high school entrepreneurial orientation scale is necessary for teachers and counselors in high schools to be able to map the level of students' entrepreneurial orientation so that high school management bodies can develop their curriculum or extra curricula activities to be more suited to fostering entrepreneurial behavior in their students.
When entrepreneurial orientation was first introduced by Miller \& Friesen (1982), this construct was discussed more from an organizational level perspective as an entrepreneurial model in companies that regularly innovate and take risks in developing strategies to launch their products to the market. Miller (1983) perfected this concept by adding the concept of proactive strategies aimed at getting rid of their competitors. This concept, which was still abstract, was further concreted by Covin \& Slevin (1989), who outlined the three entrepreneurial dimensions of proactiveness, innovativeness and risk-taking. Lumpkin \& Dess (1996) then added two additional entrepreneurial dimensions: autonomy and aggressive competitiveness. However, all of these entrepreneurial dimensions were at the organizational or top leader level, not for the members of the organization.

An entrepreneurial scale at the individual level was first examined by Bolton (2012), who developed the scale for potential business owners as individual people. Previously, Bolton \& Lane (2012) had also examined the individual entrepreneurial orientation of university students. Gorostiaga, et al (2019) developed an entrepreneurial orientation scale for vocational training students aged between 16 and 57 years. Until now, an entrepreneurial orientation scale has only been developed for high school's students by Kurniawan, et al (2019).

Research on entrepreneurial orientation in high school students conducted by Kurniawan, et al (2019) produced different exploratory factor analysis results to research conducted by Bolton and Lane (2012) on entrepreneurial orientation in university students. Bolton and Lane (2012) proved that there are three dimensions of entrepreneurial orientation in university students: innovativeness, proactiveness and risk-taking. Meanwhile, Kurniawan, et al (2019) found that there are three different dimensions of 
entrepreneurial orientation in high school students: innovativeness, risky-proactiveness and competitiveness. This difference in research results necessitates a specific study on entrepreneurial orientation in high school students and the development of a norm index for entrepreneurial orientation norms in high school students.

In the early stages of their research, Kurniawan, et al (2019) explored items based on the five dimensions developed by Lumpkin \& Dess (1996): proactiveness, innovativeness, risk-taking, autonomy and aggressive competitiveness. Based on this initial exploration stage, Kurniawan, et al (2019) swapped the aggressive competitiveness dimension with a competitiveness dimension based on personal development competitive behavior (Ryckman, et al, 1996), because it is more suitable in the context of high school students.

Based on Lumpkin and Dess's (1996) concept, the proactiveness dimension is the initiative to take a role in situations that offer opportunities or require change. The dimension of innovativeness is the behavior of seeking opportunities, thinking of new or creative ways to respond to the opportunities found, striving to produce these creative strategies, and initiating their application. The dimension of risk-taking is taking brave actions in uncertain situations, in which there is a possibility of failure or loss as a result of the efforts made (Miller \& Friesen, 1982; Covin \& Slevin,1989; Lumpkin \& Dess, 1996; and de Jong \& Wennekers, 2008).

According to Lumpkin \& Dess (1996), the dimension of autonomy is an action initiated and carried out by oneself to do something new and to believe that it will be a success. Meanwhile, the dimension of competitiveness proposed by Kurniawan, et al (2019), adapted from the concept of personal development competitiveness, is an attitude that focuses more on competitiveness in the sense of selfdevelopment, rather than simply winning (Ryckman, et al., 1996).

In the exploratory factor analysis stage, Kurniawan, et al (2019) found that only four dimensions or components were meaningful. These four components included three dimensions that had been explored previously: innovativeness, competitiveness, and autonomy, while the remaining dimension is a combination of the proactiveness and risk-taking dimensions, which was then called risky proactiveness. In the discussion, it was explained that high school students who act proactively and take the initiative to make changes may experience rejection from their peers. For high school students who are at the adolescent development stage, peer rejection is a high-risk consequence because adolescents have a need for conformity with their peers. As a result, for high school students, all proactive actions also involve their own risks (Kurniawan, et al., 2019; Frese \& Fay, 2001; Santor et al., 2000; Sandstrom,1999; Bradutanu, 2015; Lumpkin \& Dess, 1996).

During the external validity test for entrepreneurial intention conducted by Kurniawan, et al (2019), only three dimensions were found to significantly correlate: innovativeness, risky-proactiveness and competitiveness. Meanwhile, the dimension of autonomy did not significantly correlate with entrepreneurial intention. Lumpkin dan Dess (1996) developed the dimension of autonomy at the organizational level, illustrating the need for company management to provide their employees with the freedom to undertake entrepreneurial actions. This is not so relevant when applied to the construct of entrepreneurial orientation at the individual level. Many founders establish their businesses together with a partner, rather than alone, meaning that autonomy is no longer an absolute dimension in entrepreneurial orientation (Kurniawan, et al., 2019; Rauch, et al (2009); Bolton dan Lane; 2012).

This research is a continuation of the Exploratory Factor Analysis conducted by Kurniawan, et al. (2019). In their research, three dimensions were found to be relevant to the high school student entrepreneurial orientation scale: innovativeness, risky-proactiveness and competitiveness. Kurniawan, et al (2019) recommended that further research conduct a confirmatory factor analysis on a larger number of subjects in relation to the three dimensions and scale items developed in their research. Kurniawan, et al (2019) also suggested that further research needs to develop an entrepreneurial orientation norm index for junior and senior high school students so that they can be more specifically identified, mapped and acted upon by entrepreneurship teachers and school management. Therefore, this study aims to conduct a confirmatory factor analysis and develop norming for the high school student entrepreneurial orientation scale developed by Kurniawan, et al (2019).

\section{Methods}

This research was conducted based on the data of 646 high school students from six large cities throughout the provinces on Java Island, Indonesia. These six large cities are Jakarta, Tangerang, Bandung, Semarang, Yogyakarta and Surabaya. This research consists of two stages:

\section{Stage one: Confirmatory Factor Analysis}

In this research, the high school student entrepreneurial orientation scale, which was tested using exploratory factor analysis and an external validity test by Kurniawan, et al (2019), was tested using confirmatory factor analysis. Kurniawan, et al (2019)'s research, which was conducted on 368 high school students, proved that the Indonesian language scale measured by a 5-point Likert scale ( 1 = very rarely to $5=$ very often), has three entrepreneurial orientation dimensions that are relevant for high school students: innovativeness, risky proactiveness and competitiveness. Based on this result, the Cronbach $\alpha$ reliability for the three dimensions is $>0.7$ in order to meet the standard cut-off point for scale development (Nunnally \& Bernstein, 1994). The innovativeness dimension has seven valid items with CITC 0.402-0.651 and $\alpha=0.791$. The risky proactiveness dimension has nine valid items with CITC 0.562-0.659 and $\alpha=0.871$. Meanwhile, the competitiveness dimension has eight valid items with CITC $0.414-0.681$ and $\alpha=0.823$.

This research was conducted through an online survey. All participants gave informed consent before completing the survey. 


\section{Stage two: Norming}

Norm indexes are arranged according to five categories, "Very High", "High", "Medium", "Low", and "Very Low" based on the normal data distribution. In this study, norms will be arranged based on junior and senior high school groups.

\section{Results}

This research was conducted on 646 high school students with the characteristics listed in Table 1.

Table 1. Participant Characteristics $(n=646)$

\begin{tabular}{cccc}
\hline Variable & Item & Frequency & Percentage \\
\hline Gender & Male & 329 & 50.93 \\
& Female & 317 & 49.07 \\
Age & 12 years old & 45 & 6.97 \\
& 13 years old & 136 & 21.05 \\
& 14 years old & 121 & 18.73 \\
& 15 years old & 103 & 15.94 \\
& 16 years old & 175 & 27.09 \\
& 17 years old & 60 & 9.29 \\
High School & 18 years old & 4 & 0.62 \\
Level & J Junior High & 320 & 0.31 \\
& School & & 49.54 \\
& Senior High & 326 & \\
& School & & 50.46 \\
& Jakarta & 108 & 16.72 \\
& Bandung & 109 & 16.87 \\
& Tangerang & 102 & 16.72 \\
& Semarang & 109 & 16.87 \\
& Yogyakarta & 109 & 16.87 \\
& Surabaya & 109 & 16.87 \\
\hline
\end{tabular}

The assumption test for this study uses multivariate normal distribution analysis with kurtosis value. If a distribution has a kurtosis value that exceeds 3 , it is labeled "peaked" relative to the normal, and if its kurtosis value is less than 3, it is labeled "flat" relative to the normal. (Mason $\&$ Young, 2002). Following are the kurtosis values for the confirmatory factor analysis results from this study: innovativeness dimension $=8.423$, risky proactiveness dimension $=10.038 ;$ competitiveness dimension $=14.756$, and the kurtosis value for second order analysis $=92.211$. Thus, all confirmatory factor analysis tests in this study have a kurtosis value of more than 3.0, meaning they are labeled "peaked" relative to the normal or not fulfill the normality assumption test.

Although the research did not pass the multivariate normal distribution test, the study's sample size included more than 100 respondents and can, therefore, be assumed to be normally distributed (Katz, 2011). Thus, the research data fulfil the multivariate parametric test requirement. Parametric tests are preferred in multivariate situations due to the fact that non-parametric tests currently available are generally insufficient to test multivariate situations due to a lack of suitable specifications, for example strength, breadth of use, and extension of non-parametric tests in such situations (Hubbard,1978).

The first order confirmatory factor analysis test results for the innovativeness dimension are listed in Figure 1.

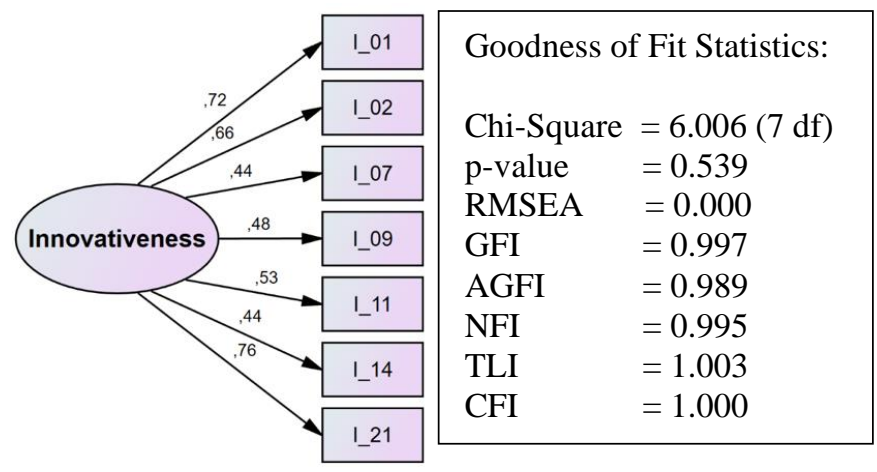

Figure 1. Confirmatory Factor Analysis for the Innovativeness Dimension

The confirmatory factor analysis results in Figure 1 show that all item groups for the innovativeness dimension are good and according to the design. All Goodness of Fit measurements meet the Good Fit criteria according to Schermelleh-Engel, Moosbrugger \& Mülleret (2003). The loading factors of all items in this dimension are $>0.5$. Construct Reliability (CR) for the innovativeness dimension is $0.782(\mathrm{CR}>0.7)$ and the Average Variance Extracted (AVE) is 0.548 (AVE > 0.5), meaning the convergence indicator for this construct is fulfilled (Hair, et al., 2010). Detailed results of loading factors, errors, AVE and CR are listed in Table 2.

The first order confirmatory factor analysis test results for the risky proactiveness dimension are listed in Figure 2.

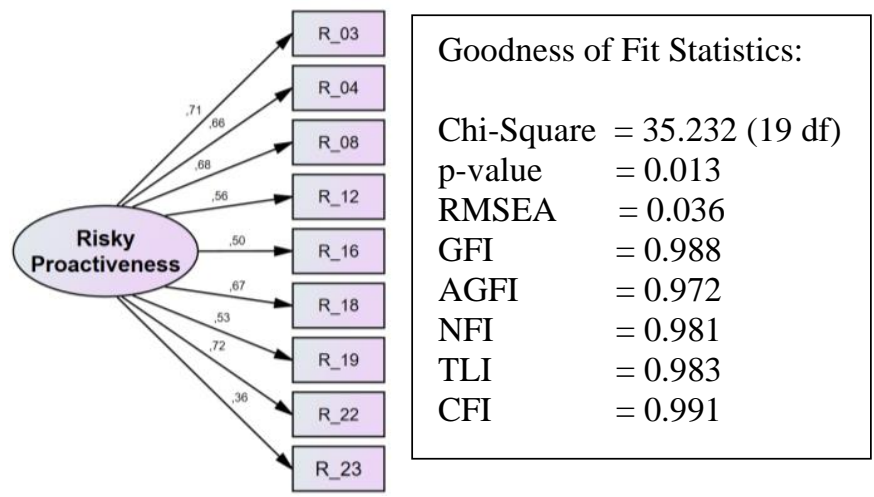

Figure 2. Confirmatory Factor Analysis for the Risky Proactiveness Dimension

The confirmatory factor analysis results in Figure 2 show that all item groups for the risky proactiveness dimension are good and according to the design. All Goodness of Fit measurements fulfil the Good Fit criteria, except for the p-value of chi-square, which is in the $0.01-$ 0.05 range, meaning it meets the "acceptable" criteria (Schermelleh-Engel, Moosbrugger \& Mülleret, 2003). The loading factors of all items in this dimension are $>0,5$. 
Construct Realibility (CR) for the risky proactiveness dimension is 0.857 ( $\mathrm{CR}>0.7)$, and the Average Variance Extracted (AVE) is 0.604 (AVE > 0.5), meaning the convergence indicator for this construct is fulfilled (Hair, et al., 2010). Detailed results of the loading factors, errors, AVE and CR are listed in Table 3.

Table 2. CFA Results for the Innovativeness Dimension

\begin{tabular}{llllc}
\hline \multicolumn{1}{c}{ Item } & $\begin{array}{l}\text { Loading } \\
\text { Factor }\end{array}$ & Errors & CR & AVE \\
\hline I_01 & $\begin{array}{l}\text { The things I do (assignments/creations) are considered by my } \\
\text { friends to be creative. }\end{array}$ & 0.72 & 0.398 \\
& $\begin{array}{l}\text { The results of my work have different characteristics to my friends. } \\
\text { I_02 }\end{array}$ & 0.66 & 0.457 \\
I_07 & $\begin{array}{l}\text { The ideas or solutions that I present are accepted by others. } \\
\text { I_09 }\end{array} \quad \begin{array}{l}\text { The ideas or solutions that I present are useful for others (e.g. } \\
\text { friends, teachers, etc.). }\end{array}$ & 0.44 & 0.526 & 0.782 \\
I_11 & I have creative ways to convince others to accept my ideas. & 0.548 \\
I_14 & I have multiple ways to solve my problems. & 0.53 & 0.683 \\
I_21 & I can be creative with school projects or tasks. & 0.44 & 0.536 \\
\hline
\end{tabular}

The first order confirmatory factor analysis test results for the competitiveness dimension are listed in Figure 3.

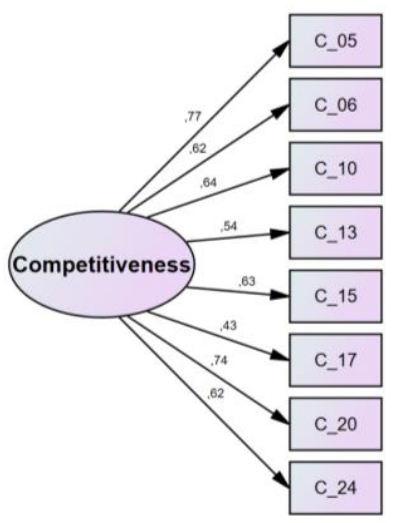

\begin{tabular}{|c|c|}
\hline \multicolumn{2}{|c|}{ Goodness of Fit Statistics: } \\
\hline Chi-Square & $=20.072(13 \mathrm{df})$ \\
\hline p-value & $=0.093$ \\
\hline RMSEA & $=0.029$ \\
\hline GFI & $=0.993$ \\
\hline AGFI & $=0.980$ \\
\hline NFI & $=0.986$ \\
\hline TLI & $=0.990$ \\
\hline CFI & $=0.995$ \\
\hline
\end{tabular}

Figure 3. Confirmatory Factor Analysis for the Competitiveness Dimension

The confirmatory factor analysis results in Figure 3 show that all item groups in the competitiveness dimension are good and according to the design. All Goodness of Fit measurements fulfil the Good Fit criteria according to Schermelleh-Engel, Moosbrugger \& Mülleret (2003). The loading factors of all items in this dimension are $>0,5$. Construct Realibility (CR) for the competitiveness dimension is $0.858(\mathrm{CR}>0.7)$ and the Average Variance Extracted (AVE) is 0.644 (AVE > 0.5), meaning the convergence indicator for this construct is fulfilled (Hair, et al., 2010). Detailed results of the loading factors, errors, AVE and CR are listed in Table 4.

The internal validity of the Confirmatory Factor Analysis results shows that each dimension has a corrected item-total correlation (CITC) score of above 0.2, which indicates a high level of correlation (Streiner, Norman, \& Cairney, 2015), and Cronbach's $\alpha$ reliability $>0.7$ (Nunnally $\&$ Bernstein, 1994). The innovativeness dimension has seven valid items, with CITC $=0.438-0.610$ and $\alpha=0.806$. The risky proactiveness dimension has nine valid items, with CITC $=0.437-0.628$ and $\alpha=0.845$. The competitiveness dimension has eight valid items, with CITC $=0.404-0.630$ and $\alpha=0.817$.

The second order confirmatory factor analysis test results for the entrepreneurial orientation construct are listed in Figure 4. The confirmatory factor analysis results in Figure 4 show that all item groups for the entrepreneurial orientation construct are good and according to the design. All Goodness of Fit measurements fulfil the Good Fit criteria according to Schermelleh-Engel, et al. (2003). The scale has been registered Copyright at the Ministry of Law and Human Rights of the Republic of Indonesia, number EC00201950720 dated 14 August 2019.

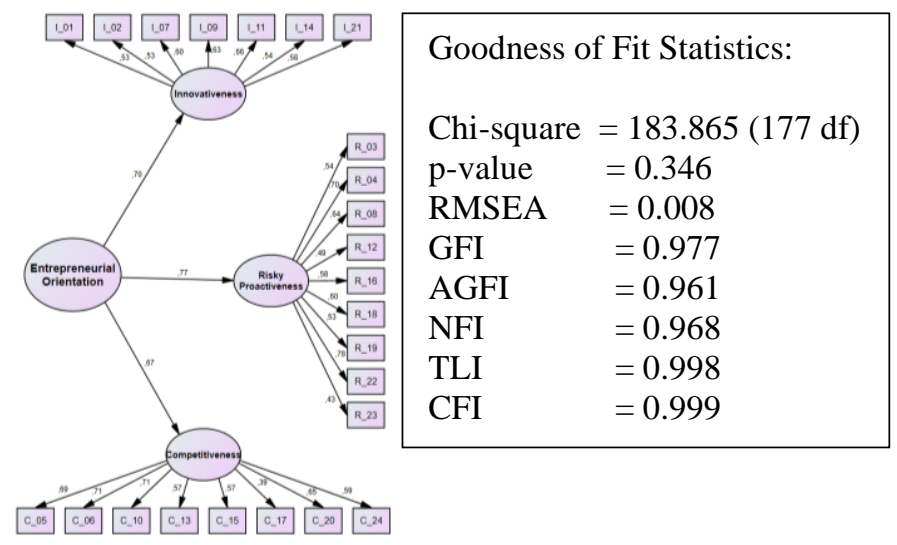

Figure 4. Confirmatory Factor Analysis for the Entrepreneurial Orientation Construct

The norm index for the junior high school group, based on the normal distribution of data and divided into five categories, is listed in Table 5. The norm index for the senior high school group, based on the normal distribution of data and divided into five categories, is listed in Table 6.

The Pearson's correlation coefficient between the students' age and entrepreneurial orientation did not reveal a significant correlation $(\mathrm{r}=0.048 ; \mathrm{p}=0.224 ; \mathrm{p}>0.05)$. 
There was also no significant correlation between the students' age and risky proactiveness $(\mathrm{r}=0.038 ; \mathrm{p}=0.333$; $\mathrm{p}>0.05)$. Likewise, there was no significant correlation between the students' age and competitiveness $(r=-0.011 ; p$
$=0.780 ; \mathrm{p}>0.05)$. Only the innovativeness dimension showed a significant positive correlation with students' age, although not very strong $(r=0,100 ; p=0.011 ; p<0.05)$.

Table 3. CFA Results for the Risky Proactiveness Dimension

\begin{tabular}{|c|c|c|c|c|c|}
\hline & Item & $\begin{array}{l}\text { Loading } \\
\text { Factor }\end{array}$ & Errors & CR & AVE \\
\hline R_03 & $\begin{array}{l}\text { I am brave enough to ask the teacher questions, despite the } \\
\text { possibility of being scolded by the teacher or ridiculed by my friends. }\end{array}$ & 0.71 & 0.678 & & \\
\hline R_04 & I offer my opinion before being asked by the teacher or my friends. & 0.66 & 0.631 & & \\
\hline R_08 & $\begin{array}{l}\text { I am brave enough to express my opinions, even though they might } \\
\text { not be accepted. }\end{array}$ & 0.68 & 0.565 & & \\
\hline R_12 & I take the initiative to ask if things are unclear. & 0.56 & 0.730 & & \\
\hline R_16 & I motivate my friends to be more actively involved in class. & 0.5 & 0.841 & 0.857 & 0.604 \\
\hline R_18 & $\begin{array}{l}\text { I am brave enough to answer the teacher's questions, even though I } \\
\text { might be wrong. }\end{array}$ & 0.67 & 0.664 & & \\
\hline R_19 & I take the initiate to invite my friends to discuss problems in class. & 0.53 & 0.896 & & \\
\hline R_22 & $\begin{array}{l}\text { I am brave enough to express opinions that are different to my } \\
\text { friends. }\end{array}$ & 0.72 & 0.464 & & \\
\hline R_23 & $\begin{array}{l}\text { I take the initiative to ask my friends to participate in school events } \\
\text { or competitions. }\end{array}$ & 0.36 & 0.158 & & \\
\hline
\end{tabular}

The students' gender also had little impact on their entrepreneurial orientation. According to independent $\mathrm{T}$ Test samples, only the risky proactiveness dimension revealed different scores when viewed in terms of gender $(\mathrm{T}-\mathrm{Test}=2.718 ; \mathrm{p}=0.003 ; \mathrm{p}<0.05)$. The mean risky proactiveness score for male students (28.757) was greater than that of the female students (27.372).

\section{Discussion}

The results of the confirmatory factor analysis in this study prove that the three dimensions of the high school student entrepreneurial orientation scale developed by Kurniawan, et al (2019) are valid and in accordance with the construct. The initial concept for the innovativeness dimension is the act of exploring challenges, developing creative ideas, striving to realize these ideas and starting to apply them (Covin \& Slevin, 1989; De \& Wennekers, 2008; Lumpkin \& Dess, 1996; Miller \& Friesen, 1982). The results of the focus group discussions held by Kurniawan, et al (2019) outline that the challenges explored in the high school context were tasks that must be completed by school students, both in the form of artistic creations and specific projects. Problems in school are also opportunities that can be explored by high school students in order to produce creative ideas that manifest themselves in creative works, projects or problem solutions.

The high school students had not been able to implement their creative ideas in broader projects due to limitations in the curriculum and teaching methods in schools. When this research was carried out, the high school education system still implemented the Indonesian national exam as a requirement. As a result, the curriculum and teaching processes applied to high school students were more focused on summative assessment, limiting the students' opportunities to implement their own creative ideas. Teachers were also powerless in developing their curriculum and teaching methods because of policies that limited them to utilizing only the standardized curriculum (Tim Redaksi Kanisius, 2008; Surakhmad, 2009). This assertion is supported by Banaji, Cramer and Perrotta (2014) in their qualitative research conducted on school stakeholders, which found that the implementation of creativity in schools was constrained by the traditional curriculum and assessment, teaching methods that are monotonous and do not value differences, and not allowing students to use digital technology. Thus, reasonable forms of innovativeness in high school students are as outlined in the innovativeness dimension items in this scale.

Unlike adults, whose proactive actions are not perceived as risks, for high school students in the adolescent development stage, proactive actions are perceived as extremely risky. Proactive actions, such as expressing opinions to peers or teachers or taking the initiative to encourage others to do something, run the risk of rejection from peers. For adolescents, peer rejection can impact their psychological condition as this developmental stage requires conformity from peers (Kurniawan, et al., 2019; Frese \& Fay, 2001; Santor et al., 2000; Sandstrom,1999; Bradutanu, 2015; Lumpkin \& Dess, 1996).

Teenagers who act proactively despite the risk of peer rejection indirectly train themselves to cope with situations where their ideas, capital proposals or movements are rejected by venture stakeholders. Pittz \& Liguori (2020) 
stated that a successful entrepreneur must be accustomed to, and even immune to, experiencing rejection so that they can be consistent in what they will achieve. This view has long been proven by Buttner and Rosen (1992) that entrepreneurs, irrespective of gender, are prepared for rejection when applying for a loan with the bank and acknowledge that this rejection would be due to their own shortcomings in developing their business plan and not the result of subjective bias. Therefore, actions classified as risky proactiveness, such as those outlined in the items of

Table 4. CFA Results for the Competitiveness Dimension

\begin{tabular}{llcc}
\multicolumn{5}{c}{ Table 4. CFA Results for the Competitiveness Dimension } & $\begin{array}{c}\text { Loading } \\
\text { Factor }\end{array}$ & Errors & CR & AVE \\
& & 0.77 & 0.311 \\
\hline C_05 & I try to find solutions for mistakes that I make. & 0.62 & 0.376 \\
C_06 & I try to do better than my previous results. & 0.64 & 0.397 \\
C_10 & I learn from my past mistakes in order to achieve better results. & 0.54 & 0.569 \\
C_13 & Mistakes that I make do not discourage me from trying again. & 0.63 & 0.483 \\
C_15 & I am to get better grades than my previous report card grades. & & 0.858 \\
C_17 & I ask for advice from my teachers or parents to improve my & 0.644 \\
& results. & 0.43 & 0.997 \\
C_20 & I try hard to achieve my target results. & 0.74 & 0.305 \\
C_24 & I make the most of my time in order to improve my results. & 0.62 & 0.520 \\
\hline
\end{tabular}

this scale, may indicate the extent to which teenagers are ready to overcome business rejection in their adulthood.

Aggressively competitive behavior, as one of the entrepreneurial orientation dimensions developed by Lumpkin \& Dess (1996), is not relevant to the context of high school students. According to Bolton \& Lane (2012), it is more suitable to apply aggressive competitive behavior in business situations that are full of risks and, therefore, is less relevant when applied to the context of high school students (Kurniawan, et al, 2019). The competitiveness dimension in this scale refers more to the construct of personal development competitiveness developed by Ryckman, Hammer, Kaczor, \& Gold (1996). Learning from failure, asking for feedback from teachers and parents, and striving to achieve better results are forms of competitive behavior that are more relevant to high school students.

Andre (2013) proved that many entrepreneurs exhibit more personal development competitive behaviors than ones that are aggressive or hypercompetitive. The results of a study conducted on high school and university students proved that personal development competitiveness correlates positively with motivation to perform well (Orosz, et al., 2018). Meanwhile, the results of the Collins, Hanges \& Locke (2004) meta-analysis indicate that motivation to perform well correlates significantly with entrepreneurial career choices and entrepreneurial performance. Thus, personal development competitive behaviors, such as those outlined in the competitiveness dimension items in this scale, may indicate career choices and good performance as an entrepreneur in the future.

The norm index results show that senior high school students have higher norm standards than junior high school students, especially for the innovativeness and the risky proactiveness dimensions. The study also revealed a positive correlation between students' age and innovativeness, although the correlation was not very strong. Parsons' (2015) literature review found that the higher a person's age, the higher their propensity for innovation until the peak age of around 50 years, after which it will decrease. High school aged students, who are still far below 50 years, are still in the stage of improvement, meaning the standard norm of innovativeness for senior high school students is higher than for junior high school students. The results of Card \& Little's (2006) meta-analytic review indicate that the higher a teenager's age, the more their reactive aggression turns into proactive action. This explains why the risky proactiveness norm standard is higher in senior high school students than in junior high school students.

The study results also indicate that male students have stronger risky proactiveness than female students. Previous research conducted on small and medium-sized enterprise owners has also proven that there are differences in risktaking and proactiveness between genders (Neneh, Zyl and Noordwyk, 2016). This finding is also in agreement with the results of a study conducted by Kumar, Paray \& Dwivedi (2020), which proved that male university students are more proactive than female university students. Likewise, Kurniawan's (2015) research proved that male university students are more risk-taking and proactive than female university students. Women are often stereotyped as having more emotional and nurturing traits, while men are stereotyped as being aggressive and independent. These stereotypes lead them to behave in accordance with expectations and, as a result, female students are less bold in taking initiative and risks compared to male students (Kurniawan, 2015). 
Table 5. Norm Index for Junior High School Students

\begin{tabular}{|c|c|c|c|c|c|}
\hline Construct & Very Low & Low & Medium & High & Very High \\
\hline Innovativeness & $\leq 14.60$ & $14.61-19.20$ & $19.21-23.80$ & $23.81-28.40$ & $\geq 28.41$ \\
\hline Risky Proactiveness & $\leq 18.20$ & $18.21-24.40$ & $24.41-30.60$ & $30.61-36.80$ & $\geq 36.81$ \\
\hline Competitiveness & $\leq 21.25$ & $21.26-25.94$ & $25.95-30.63$ & $30.64-35.31$ & $\geq 35.32$ \\
\hline \multicolumn{6}{|l|}{ Entrepreneurial } \\
\hline \multicolumn{6}{|c|}{ Table 6. Norm Index for Senior High School Students } \\
\hline Construct & Very Low & Low & Medium & High & Very High \\
\hline Innovativeness & $\leq 16.25$ & $16.26-20.94$ & $20.95-25.63$ & $25.64-30.31$ & $\geq 30.32$ \\
\hline Risky Proactiveness & $\leq 19.40$ & $19.41-25.80$ & $25.81-32.20$ & $32.21-38.60$ & $\geq 38.61$ \\
\hline Competitiveness & $\leq 18.40$ & $18.41-23.80$ & $23.81-29.20$ & $29.21-34.60$ & $\geq 34.61$ \\
\hline $\begin{array}{c}\text { Entrepreneurial } \\
\text { Orientation }\end{array}$ & $\leq 56.80$ & $56.81-75.10$ & $75.11-93.40$ & $93.41-111.70$ & $\geq 111.71$ \\
\hline
\end{tabular}

The theoretical implications of this study are adding insight into the development of the entrepreneurial orientation scale for high school students and its norming. This research also has practical implications for secondary school teachers and counsellors in mapping their students' entrepreneurial orientation levels. Based on this mapping of students' entrepreneurial orientation, secondary school management bodies can prepare a curriculum or extracurricular activities that are more appropriate to developing entrepreneurial behaviors in students.

A limitation of this study is its population, which were all private schools. Further studies are recommended to validate and develop this scale in public high schools. The study also does not identify the socioeconomic status (SES) of the students and further studies are, therefore, recommended to examine the relationship between students' SES and entrepreneurial orientation

\section{Acknowledgement}

We acknowledge the support and generosity of Kemenristek Dikti Republic of Indonesia as well as Grant of Penelitian Terapan Unggulan Perguruan Tinggi (PTUPT) 2019 for this research.

\section{References}

1. Banaji, S.; Cranmer, S. \& Perotta, C. (2014). What's stopping us? Barriers to creativity and innovation in schooling across Europe. LSE Research Online. Retrieved on June 5, 2020 at http://eprints.lse.ac.uk/55204/1/Banaji_Cranmer_P errotta_What\%27s-stopping-us_2013.pdf.

2. Bolton, D. L., \& Lane, M. D. (2012). Individual entrepreneurial orientation: Development of a measurement instrument. Education + Training, 54(2), 219-233. doi:10.1108/00400911211210314

3. Bradutanu, D. (2015). Resistance to change - a new perspective: A Textbook For Managers Who Plan To Implement A Change. Raleigh: Lulu.com.

4. Buttner, E.H. \& Rosen, B. (1992). Rejection in the loan application process: Male and female entrepreneurs' perceptions and subsequent intentions. Journal of Small Business Management, January 1992. https://www.researchgate.net/ publication/283363362_Rejection_in_the_loan_ap plication_process_Male_and_female_entrepreneurs '_perceptions_and_subsequent_intentions

5. Card, N.A. \& Little, T.D. (2006). Proactive and reactive aggression in childhood and adolescence: A meta-analysis of differential relations with psychosocial adjustment. International Journal of Behavioral Development, 30 (5), 466-480. DOI: $10.1177 / 0165025406071904$

6. Collins, C., Hanges, P. J., \& Locke, E. (2004). The relationship of achievement motivation to entrepreneurial behavior: A meta-analysis. Human Performance, 17(1), 95-117. DOI: https://doi.org/10.1207/S15327043HUP1701_5

7. Covin, J. G., \& Slevin, D. P. (1989). Strategic management of small firms in hostile and benign environments. Strategic Management Journal, 10, 75-87. doi:10.1002/smj.4250100107

8. de Jong, J. \& Wennekers, S. (2008). Intrapreneurship: Conceptualizing Entrepreneurial Emplooyee Bahaviour. Scientific analysis of entrepreneurship and SMEs. Diakses dari http://www.entrepreneur ship-sme.eu/pdf-ez/H200802.pdf

9. Frese, M., \& Fay, D. (2001). Personal initiative (PI): An active performance concept for work in 
the $21^{\text {st }}$ century. In B. M. Staw \& R. M. Sutton (Eds.), Research in Organizational Behavior (Vol. 23, pp. 133-187). Amsterdam: Elsevier Science.

10. Gorostiaga, A; Aliri, J; Ulacia, I; Soroa, G; Balluerka, N.; Aritzeta, A. \& Muela, A. (2019). Assessment of entrepreneurial orientation in vocational training students: development of a new scale and relationships with self-efficacy and personal initiativefrontiers in psychology. Frontiers in Psychology, 10, May 2019. doi: 10.3389/fpsyg.2019.01125

11. Hair, J.F., Anderson, R.E., Babin, B.J. \& Black, W.C. (2010). Multivariate data analysis: A global perspective (Vol. 7). Upper Saddle River, NJ: Pearson.

12. Hubbard,R. (1978). The Probable Consequences of Violating the Normality Assumption in Parametric Statistical Analysis. JSTOR 10 (5), 393- 398. http://www.jstor.org/stable/ 20001404 .

13. Katz, M.H. (2011). Multiavariable Analysis: A Practical Guide for Clinicians and Public Health Researchers. Cambridge University Press.

14. Kumar, S., Paray, Z.A. \& Dwivedi, A.K. (2020). Student's entrepreneurial orientation and intentions A study across gender, academic background, and regions. Higher Education, Skills and Work-Based Learning. Emerald Publishing Limited. doi: 10.1108/HESWBL-01-2019-0009

15. Kurniawan, J.E. (2015). Perbedaan Orientasi Kewirausahaan dan Prestasi Akademik antara Mahasiswa Laki-laki dan Perempuan di Program Studi Psikologi Universitas Ciputra. Seminar Nasional "Selamatkan Indonesia, untuk Indonesia Berkarakter". Fakultas Psikologi Universitas Islam Sultan Agung (Unissula). https://dspace.uc.ac.id/bitstream/handle/123456789 /1053/RS1505002.pdf?sequence $=1 \&$ isAllowed $=\mathrm{y}$

16. Kurniawan, J. E., Setiawan, J. L., Sanjaya, E. L., Wardhani, F. P. I., Virlia, S., Dewi, K., et al. (2019). Developing a measurement instrument for high school students' entrepreneurial orientation. Cogent Ed. 6:1564423. doi: 10.1080/2331186X.2018.1564423

17. Lumpkin, G. T., \& Dess, G. G. (1996). The entrepreneurial clarifying it construct and linking orientation. Academy of Management Review, 21(1), 135-172. doi:10.2307/258632

18. Mason, R.L. \& Young, J.C. (2002). Multivariate Statistical Process Control with Industrial Applications. ASA-SIAM Series on Statistics and Applied Mathematics. https://doi.org/10.1137/1.9780898718461

19. Miller, D. (1983). The correlates of entrepreneurship in three types of firms. Management Science, 29, 770-791. doi:10.1287/mnsc.29.7.770

20. Miller, D., \& Friesen, P. H. (1982). Innovation in conservative and entrepreneurial firms: Two models of strategic momentum. Strategic Management Journal, 3(December1980), 1-25. doi:10.1002/smj.4250030102

21. Neneh, B.N., Van Zyl, J.H. and Van Noordwyk, A. (2016). Gender Differences in Entrepreneurial Orientation and Performance: Evidence from South Africa. Proceedings of the 28th Annual Conference of the Southern African Institute of Management Scientists.

22. Nunnally, J. C., \& Bernstein, I. H. (1994). Psychometric theory (3rd ed.). New York: McGraw-Hill.

23. Orosz, G., Tóth-Király, I., Büki, N., Ivaskevics, K., Böthe, B., Fülöp, M. (2018). The four faces of competition: The development of the multidimensional competitive orientation inventory. Frontiers in Psychology, 9, 779. doi:10.3389/fpsyg.2018.00779

24. Parsons, R.A. (2015), The impact of age on innovation. Management Research Review, Vol. 38 Iss 4 pp. $404-420 . \quad$ DOI: http://dx.doi.org/10.1108/MRR-10-2013-0241

25. Pittz, T.G. \& Liguori, E.W. (2020). The entrepreneur's guide to risk and decisions: Building early successful early-stage ventures. Emerald Publishing.

26. Rauch, A.,Wiklund, J., Lumpkin, G. T., \& Frese, M. (2009). Entrepreneurial orientation and business performance: An assessment of past research and suggestions for the future. Entrepreneurship: Theory and Practice, 33, 761-787. doi:10.1111/j.1540-6520.2009.00308.x

27. Ryckman, R. M., Hammer, M., Kaczor, L. M., \& Gold, J. A. (1996). Construction of a personal development competitive attitude scale. Journal of Personality Assessment, 66(2), 374-395. doi:10.1207/s15327752jpa6602_15

28. Sandstrom, J. J. (1999). A developmental perspective on peer rejection: Mechanisms of stabiliy and change. Child Development, 70(4), 955-966. doi:10.1111/1467-8624.00069

29. Santor, D. A., Messervey, D., Kusumakar, V., Messervey, D., Kusumakar, V., Messervey, D., \& Kusumakar, V. (2000). Measuring peer pressure, popularity, and conformity in adolescent boys and girls: \RPredicting school performance, sexual attitudes, and substance abuse. Journal of Youth \& Adolescence, 29(2), 163-182. doi:10.1023/a:1005152515264

30. Saw, G. K., \& Schneider, B. (2012). Tracing entrepreneurship orientation in adolescence to business ownership. International Journal of Developmental Sciences, 6 (3-4), 151-165. doi:10.3233/DEV-2012-12110

31. Schermelleh-Engel, K., Moosbrugger, H., and Müller, H. (2003). Evaluating the fit of structural equation models: tests of significance and 
descriptive goodness-of-fit measures. Methods of Psychological Research. 8, 23-74.

32. Schmitt-Rodermund, E. \& Vondracek. (2002). Occupational dreams, choices and aspirations: adolescents' entrepreneurial prospects and orientations. Journal of Adolescence, 25, 65-78. doi:10.1006/jado.2001.0449

33. Streiner, D. L., Norman, G. R., \& Cairney, J. (2015). Health measurement scales: A practical guide to their development and use (5th ed.). Oxford: Oxford University Press.

34. Surakhmad, W. (2009). Pendidikan nasional. Strategi dan tragedi. Jakarta: Penerbit Buku Kompas.

35. Tim Redaksi Kanisius. (2008). Paradigma pedagogi reflektif. Alternatif solusi menuju idealisme pendidikan kristiani. Yogyakarta: Kanisius.

\section{Appendix 1: High School Student's Entrepreneurial Orientation Items in Indonesian language}

\section{Innovativeness Dimension}

I_01 Hal yang saya kerjakan (tugas/karya) dianggap kreatif oleh teman-teman saya.

I_02 Hasil karya saya memiliki ciri khas yang berbeda dengan teman-teman yang lain.

I_07 Ide atau solusi yang saya berikan diterima oleh orang lain.

I_09 Ide atau solusi yang saya berikan bermanfaat bagi orang lain (mis: teman,guru, dsb).

I_11 Saya memiliki cara yang kreatif untuk meyakinkan orang lain agar ide saya diterima.

I_14 Saya memiliki beberapa cara untuk menyelesaikan masalah saya.

I_21 Saya dapat membuat karya yang kreatif dalam proyek-proyek atau tugas sekolah.

\section{Risky Proactiveness Dimession}

R_03 Saya berani bertanya kepada guru walaupun ada kemungkinan untuk dimarahi guru atau diejek teman saya.

R_04 Saya mengusulkan pendapat sebelum diminta oleh guru atau teman saya.

R_08 Saya berani mengungkapkan pendapat walaupun belum tentu diterima.

R_12 Saya berinisiatif untuk bertanya ketika ada hal yang kurang jelas.

R_16 Saya menggerakkan teman-teman untuk lebih terlibat aktif di kelas.

R_18 Saya berani menjawab pertanyaan guru walaupun belum tentu benar.

R_19 Saya berinisiatif mengajak teman-teman mendiskusikan permasalahan yang ada di kelas.

R_22 Saya berani menyampaikan pendapat yang berbeda dengan teman-teman yang lain.

R_23 Saya berinisiatif mengajak teman-teman saya untuk berpartisipasi dalam acara atau lomba di sekolah.

\section{Competitiveness Dimension}

C_05 Saya berusaha mencari solusi dari suatu kegagalan yang pernah saya alami.

C_06 Saya berusaha lebih baik dari pencapaian saya sebelumnya.

C_10 Saya belajar dari kegagalan sebelumnya untuk mendapatkan hasil yang lebih baik.

C_13 Setiap kegagalan yang saya alami tidak mematahkan semangat saya untuk terus mencoba.

C_15 Saya memiliki target untuk mendapat nilai yang lebih baik dari nilai rapor saya yang sebelumnya.

C_17 Saya meminta saran dari guru atau orang tua untuk memperbaiki pencapaian saya.

C_20 Saya berusaha lebih keras untuk mengejar target pencapaian saya.

C_24 Saya memanfaatkan waktu semaksimal mungkin untuk meningkatkan pencapaian saya. 
PSYCHOLOGY AND EDUCATION (2021) 58(2): 17-26

An Interdisciplinary Journal

- The scale has been registered Copyright at the Ministry of Law and Human Rights of the Republic of Indonesia, number EC00201950720 dated 14 August 2019. 